\title{
Dehydration of Gypsum Rock by Solar Energy: Preliminary Study
}

\author{
Aurora López-Delgado¹, Sol López-Andrés², Isabel Padilla1, Marta Alvarez², \\ Roberto Galindo1, Alfonso José Vázquez ${ }^{1}$ \\ ${ }^{1}$ National Centre for Metallurgical Research, CENIM-CSIC, Madrid, Spain \\ ${ }^{2}$ Department of Crystallography and Mineralogy, Faculty of Geology, UCM, Madrid, Spain \\ Email: alopezdelgado@cenim.csic.es
}

Received 27 May 2014; revised 20 June 2014; accepted 12 July 2014

Copyright (C) 2014 by authors and Scientific Research Publishing Inc.

This work is licensed under the Creative Commons Attribution International License (CC BY). http://creativecommons.org/licenses/by/4.0/

c) (i) Open Access

\begin{abstract}
The dehydration process of gypsum rock was studied under concentrated solar energy by using a Fresnel lens with power density of $260 \mathrm{Wcm}^{-2}$. Temperatures higher than $700^{\circ} \mathrm{C}$ were attained for 1 min of solar exposure. The effect of grain size of sample and radiation exposure time on the formation of bassanite and anhydrite was studied by XRD. The complete transformation of dihydrate into hemihydrate and/or anhydrate phases is complete for the finer size sample. Plaster composed of $92.7 \%$ of anhydrite and $7.3 \%$ of bassanite was obtained for $5 \mathrm{~min}$ of solar exposure. Morphological and textural modifications were followed by SEM and interferometric/confocal profilometer.
\end{abstract}

\section{Keywords}

Gypsum, Bassanite, Anhydrite, Concentrated Solar Energy, Fresnel Lens

\section{Introduction}

Natural gypsum is a rock composed principally of $\mathrm{CaSO}_{4} \cdot 2 \mathrm{H}_{2} \mathrm{O}$. The various gypsum deposits differ in purity, structure, and color. The major impurities are calcium carbonate (limestone), dolomite, marl, clay and less frequently, silica, bitumen, glauberite, syngenite, and polyhalite [1]. Gypsum is one of the most widely used minerals in the world, not only in construction but also in ceramics (mold manufacture, sanitary wares, chalk and artistic sculptures), agriculture (soil conditioner), medicine (to make plaster bandages, in the manufacture of surgical and dental molds and production of toothpaste), chemical and pharmaceutical industry (as a calcium source, drugs component and lipsticks) and in food industry (water treatment, cleaning of wines, refined sugar, canned vegetables and animal feed) [2]. Spain is the third largest world producer, and the leader in production and con- 
sumption in Europe [3] [4].

Plaster is obtained by calcination of gypsum, a chemical sedimentary rock coming from evaporation phenomena in saline basins [5]. For building industry, different calcination temperatures are employed according to uses, ranging from $100^{\circ} \mathrm{C}-1400^{\circ} \mathrm{C}$, generating compositions with several phases and content within the system gypsum-bassanite-anhydrite. Their industrial applications are based on the reversibility of the dehydration-rehydration reactions of gypsum: it is partially or totally dehydrated by heating (Equations (1) and (2)) but when it is rehydrated, sets and yields hardened products. Mixtures of phases in the $\mathrm{CaSO}_{4} \cdot \mathrm{H}_{2} \mathrm{O}$ system are commonly produced during manufacture, rather than pure ones [6].

$$
\begin{gathered}
\mathrm{CaSO}_{4} \cdot 2 \mathrm{H}_{2} \mathrm{O}+\text { heat } \rightarrow \mathrm{CaSO}_{4} \cdot 1 / 2 \mathrm{H}_{2} \mathrm{O}+3 / 2 \mathrm{H}_{2} \mathrm{O} \\
\mathrm{CaSO}_{4} \cdot 2 \mathrm{H}_{2} \mathrm{O}+\text { heat } \rightarrow \mathrm{CaSO}_{4}+2 \mathrm{H}_{2} \mathrm{O}
\end{gathered}
$$

Industrially, to get commercial products, it is more important that dehydration is achieved in the shortest time to minimize energy consumption, that is the major cost of this process, taking into account the raw material cost is very low [7]. Besides, if the energy comes from fossil fuels then the environmental cost is also high. For handmade or artisanal production, gypsum is produced in small air furnaces installed in the vicinity of production sites, and in many cases they are made by users for their own consumption. Figure 1 shows a traditional furnace. In these furnaces, partial dehydration takes several hours, with continuous feeding of fuel. After the shutdown and cooling of the facility, the furnace is dismantled and calcination product is grinded. The resulting plaster is composed of multiphase calcium sulphate [8].

Sun light is a renewable energy source, which concentrated by means of Fresnel lens, can be used in thermochemical transformation, thanks to its high optical efficiency [9]-[11]. Within the current framework of technological development one of the goals of the most advanced societies is energy saving and especially the consumption of domestic and non-polluting fuel. Although the industrial use of concentrated solar radiation has the disadvantage of its intermittent nature, the use of this energy would represent a significant cost reduction for high-temperature processes, because the energy is supplied by a free and inexhaustible source as the sun, collaborating with environmental conservation. Its use is unquestionable for strong insulation countries such as Spain, the annual average insulation varies between $3.2-5.2 \mathrm{kWh} \cdot \mathrm{m}^{-2}$. Solar radiation hits the ground with a solid angle of 32 minutes, resulting in a moderate temperature of the earth's surface. A method for obtaining higher temperatures is achieved using lenses or mirrors that produce an optic deflection of the incident direct solar radiation through refraction and reflection respectively, i.e. using solar concentrators which have power efficiency much higher than systems based on photovoltaic solar energy [12] [13].

Thus, the objective of this work is to study the viability of the use a clean, non-contaminating and free power source as solar thermal energy for obtaining plaster from the calcination of gypsum rock. In order to study the influence of the grain size in the transformation of dihydrate phase (gypsum) into hemihydrate phase (bassanite)

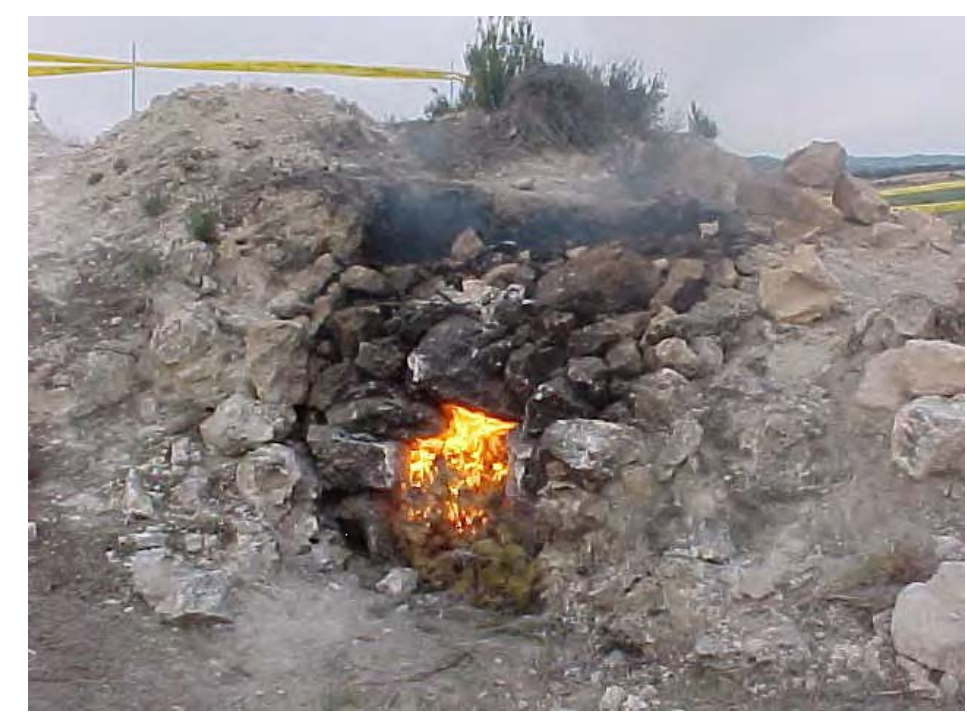

Figure 1. Handmade gypsum furnace. In Aguaviva (Teruel, Spain) [8]. 
and anhydrate phase (anhydrite), rock was crushed at different particle sizes. Tests were performed at different time spans (1 - $5 \mathrm{~min}$ ). Samples were characterized by x-ray diffraction (XRD) and microscopic techniques. This is a preliminary study focusing on the viability of the application of SEC (solar energy concentrator) for the treatment of gypsum-based materials such as: construction and demolition waste (C \& DW), gypsum from flue gas desulfurization plants (FGD), and phosphogypsum (PG).

\section{Material and Methods}

\subsection{Materials}

A sample of gypsum rock was collected from an outcrop from Morata de Tajuña, Madrid (Spain). This is a geographical area in the center of the Iberian Peninsula, with large amounts of limestone and gypsum (Figure 2). The inhabitants of this region have traditionally taken advantage of this mineral wealth for lime and plaster manufacture, by using handmade or artisanal furnaces [14].

To study the influence of the grain size in the transformation of dihydrate calcium sulfate phase into bassanite and anhydrite, the gypsum rock was crushed at different particle sizes. The particle size distribution of the ground sample is collected in Figure 3.

For the proposal of this work, only major fractions were used. From hereinafter, samples are referred as G4 (sample with particle size $>4 \mathrm{~mm}$ ), G2 (sample with particle size between 4 and $2 \mathrm{~mm}$ ) and G1 (sample with particle size between 2 and $1 \mathrm{~mm}$ ). Fine particle size fractions were rejected.

\subsection{Solar Energy Concentrator (SEC)}

The Solar radiation was concentrated by means of a Fresnel Lens made of a very high optical quality acrylic material, (polymethylmethacrylate, PMMA) [15]. The lens is positioned on an aluminum installation which has a polar axis. The lens movement from east to west is controlled automatically by a computer and the solar height is hand positioned. Figure 4 shows the solar installation (CENIM, CSIC) with a magnification of the sample chamber which is made of stainless steel and the thermocouple positioned into the sample crucible. The physical characteristic of the lens are: diameter $889 \mathrm{~mm}$, thickness $3.17 \mathrm{~mm}$, focal distance $757 \mathrm{~mm}$, refraction index 1.49 , and $92 \%$ transmission in the range of $400-1100 \mathrm{~nm}$. It is a plane convex circular lens with its grooves (50 in $25 \mathrm{~mm}$ ) toward the focus. It has a circular focus of $8 \mathrm{~mm}$ diameter and if it is positioned perpendicular to solar radiation the power density at the focus on a clear day with irradiance of $1 \mathrm{~kW} \cdot \mathrm{m}^{-2}$ is $260 \mathrm{~W} \cdot \mathrm{cm}^{-2}$, it means that the lens concentrates more than 2600 times the incident solar radiation. Figure 5 shows the 3D distribution of concentration factor [15]-[17].

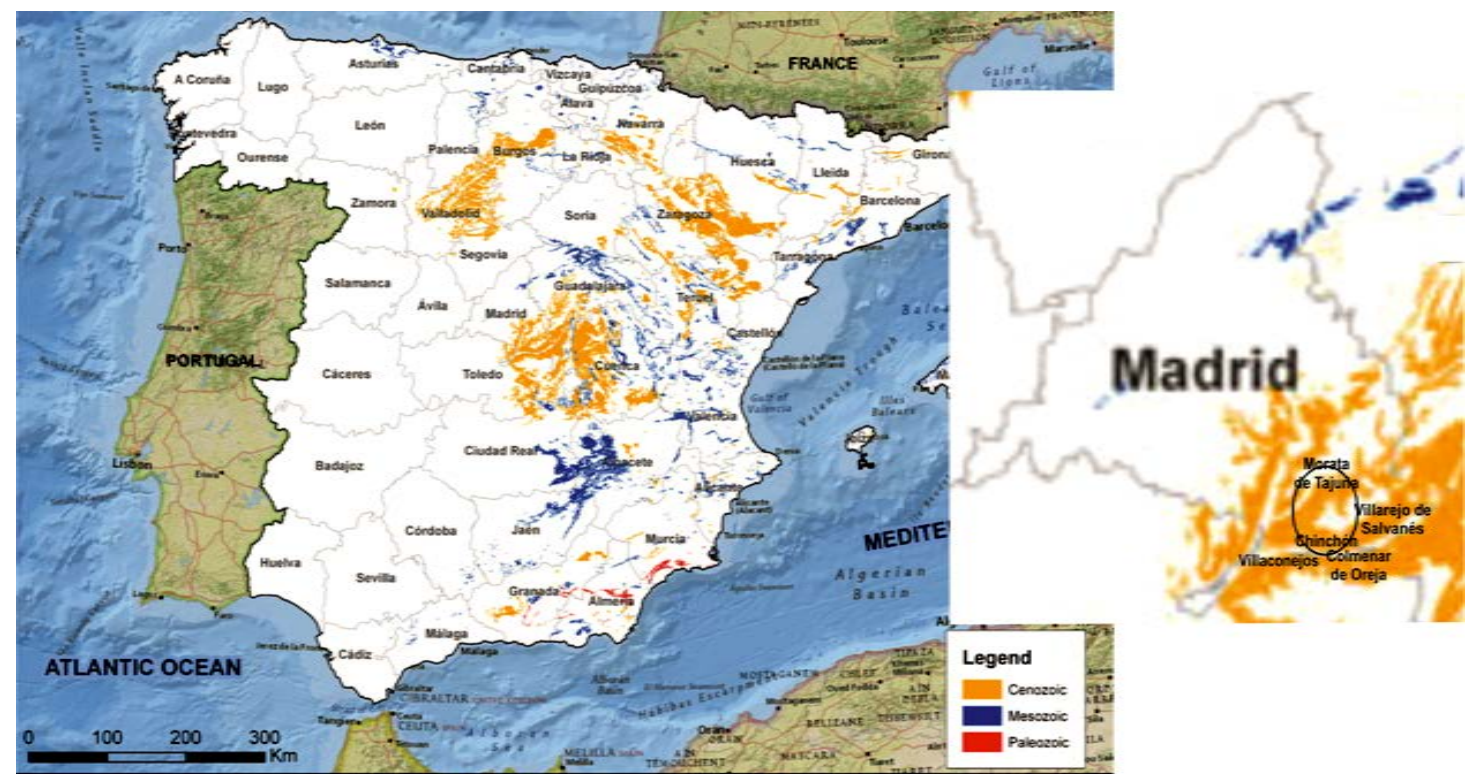

Figure 2. Geographical distribution of gypsum in Spain and localitation of the source of gypsum rock. 


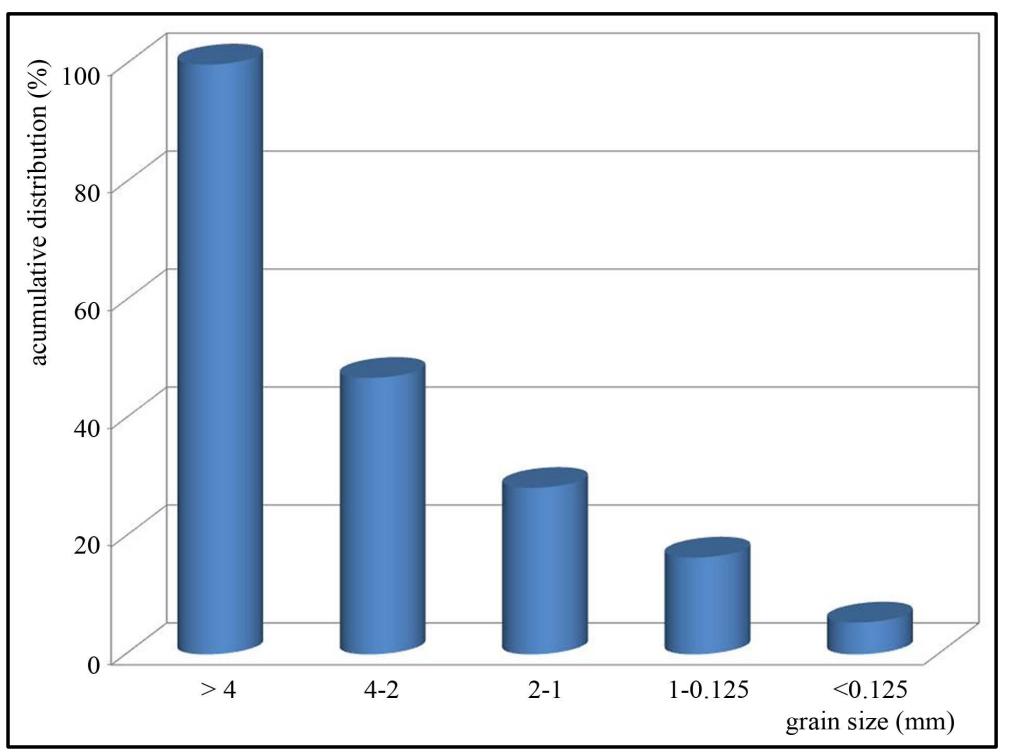

Figure 3. Particle size distribution of the ground gypsum rock.

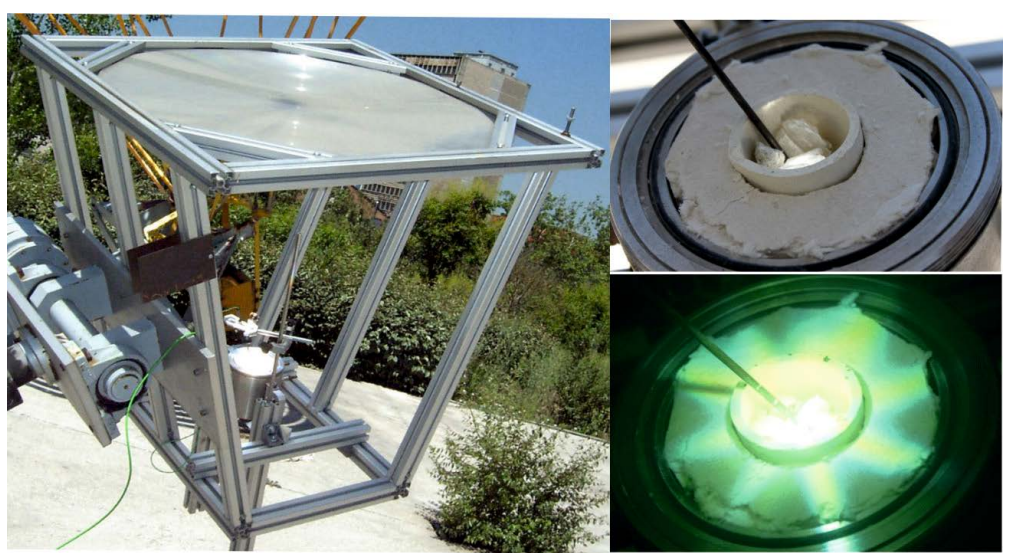

Figure 4. Solar energy concentrator (Fresnel lens). Detail of the sample chamber (before (upper right) and during solar exposure (lower right)) and the positioned thermocouple.

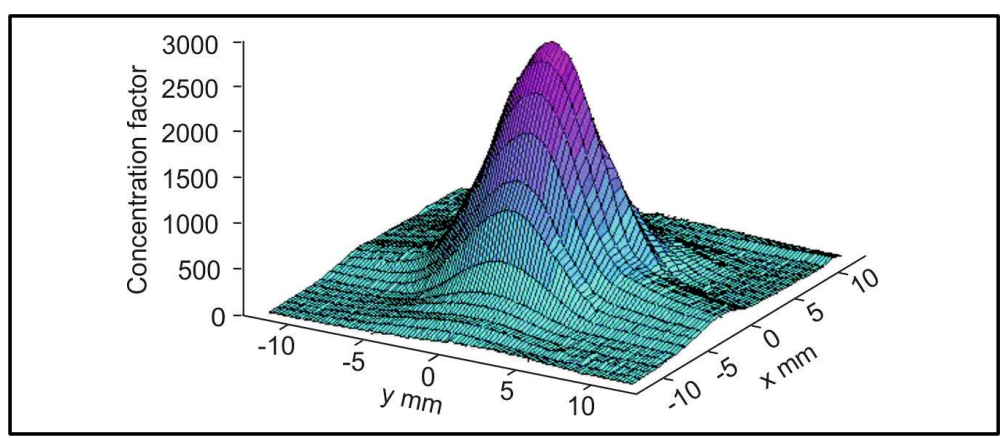

Figure 5. Distribution of the concentration factor in Fresnel lens.

\subsection{Experimental}

The Samples of different particle size of natural gypsum were placed into the sample chamber of the SEC (Figure 4) to the optimal focal distance. Alumina crucibles $(6.5 \mathrm{~cm}$ height and $6.5 \mathrm{~cm}$ diameter) were loaded with 
$25.00 \pm 0.01 \mathrm{~g}$ of sample. Temperature was measured by a type $\mathrm{K}$ thermocouple placed in the middle of sample. Tests were carried out at different solar radiation exposure time from 1 to $5 \mathrm{~min}$, in summer, during the local time of the highest radiation (12:00 to 16:00 pm). An example of solar radiation (global, diffuse and direct) during summer 2012 is shown in Figure 6.

\subsection{Characterization Techniques}

The chemical composition of the samples was determined by X-ray fluorescence (XRF, PANalytical AXIOS wavelength-dispersive X-ray spectrometer) on compacted specimen of 37mm diameter. X-ray diffraction (XRD) measurements for identification of crystalline phases were carried out using a Bruker D8 advance diffractometer with $\mathrm{Cu} \mathrm{K} \alpha$ radiation (1.541874 $\AA$ ). XRD data were collected over a $2 q$ range of $2^{\circ}-65^{\circ}$ with a step width of $0.02^{\circ}$ and time per step of $1 \mathrm{~s}$. Morphological characterization of the samples was performed by scanning electron microscopy (SEM) in a Jeol JSM-820 equipment. For those observations, samples were sputter coated with gold to make them conductive. Topographic observations of the samples surface were carried out by a optical profilometer with dual confocal and interferometric technology (PLm 2300 Optical Image Profile Sensofar).

\section{Results and Discussion}

The chemical composition of the different grain size fractions of initial gypsum sample, obtained by XRF and expressed as oxides wt.\%, is collected in Table 1 . The content in calcium sulfate is higher in fractions with larger grain size, lower in larger grain size fractions. The increase of silica, magnesium, aluminum and other elements in lower grain size fractions can be attributable to the higher content of clay in these fractions.

The XRD pattern of the initial sample is shown in Figure 7, corresponding to a highly crystalline material with narrow and well-defined diffraction peaks. The crystalline phase identified by comparison with the powder diffraction data (JCPDS files) is mostly $\mathrm{CaSO}_{4} \cdot 2 \mathrm{H}_{2} \mathrm{O}$ (JCPDS 01-070-0982). Minor crystalline phases were not identified.

The evolution of temperature during tests performed at different exposure time is shown in Figure 8. As can be seen, there is a prompt arising of temperature when lens is uncovered and values of temperature higher than $700^{\circ} \mathrm{C}$ were achieved at very short exposure time (lower than $1 \mathrm{~min}$ ). The heating rate calculated from temperature curve was $13-14^{\circ} \mathrm{C} \cdot \mathrm{s}^{-1}$.

XRD patterns of different grain size fractions of the initial sample and the samples obtained after solar radiation during different exposure time are shown in Figure 9. The transformation of dihydrate into hemihydrate started to occur at the first minute of exposure for both samples. According to the XRD results the transformation of the phase $\mathrm{CaSO}_{4} \cdot 2 \mathrm{H}_{2} \mathrm{O}$ for $1 \mathrm{~min}$ of exposure, it is higher in G2 (sample with larger grain size) than in G1, but this situation is not very remarkable for $2 \mathrm{~min}$ of exposure. For $2 \mathrm{~min}$ it is observed de coexistence of the three phases. When samples are subjected at 5 min of exposure, diffraction peaks of dihydrate phase are not observed in any sample.

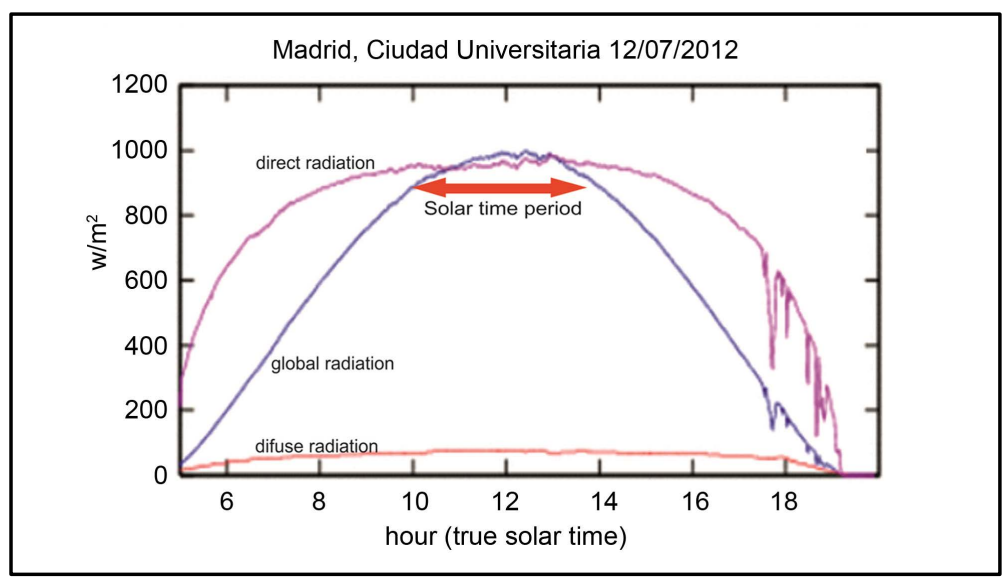

Figure 6. Local solar radiation curves according to AEMet (Spanish Agency of Meteorology http://www.aemet.es). 
Table 1. Chemical analysis by XRF of initial gypsum for the different grain size fractions (oxides wt\%).

\begin{tabular}{cccccccccccccc}
\hline $\begin{array}{c}\text { wt\% } \\
\text { Sample }\end{array}$ & $\mathrm{SO}_{3}$ & $\mathrm{CaO}$ & $\mathrm{SiO}_{2}$ & $\mathrm{MgO}$ & $\mathrm{Al}_{2} \mathrm{O}_{3}$ & $\mathrm{SrO}$ & $\mathrm{Fe}_{2} \mathrm{O}_{3}$ & $\mathrm{~K}_{2} \mathrm{O}$ & $\mathrm{TiO}_{2}$ & $\mathrm{P}_{2} \mathrm{O}_{5}$ & $\mathrm{BaO}$ & $\mathrm{MnO}$ & $\mathrm{NiO}$ \\
\hline $\mathrm{G} 4$ & 49.06 & 43.31 & 2.88 & 2.65 & 0.85 & 0.64 & 0.36 & 0.16 & 0.04 & 0.02 & 0.02 & - & - \\
$\mathrm{G} 2$ & 47.51 & 42.81 & 3.02 & 4.32 & 0.90 & 0.77 & 0.38 & 0.17 & 0.04 & 0.03 & 0.04 & 0.01 & 0.01 \\
$\mathrm{G} 1$ & 46.31 & 42.10 & 3.95 & 4.81 & 1.10 & 0.85 & 0.53 & 0.24 & 0.06 & 0.03 & - & - & - \\
\hline
\end{tabular}

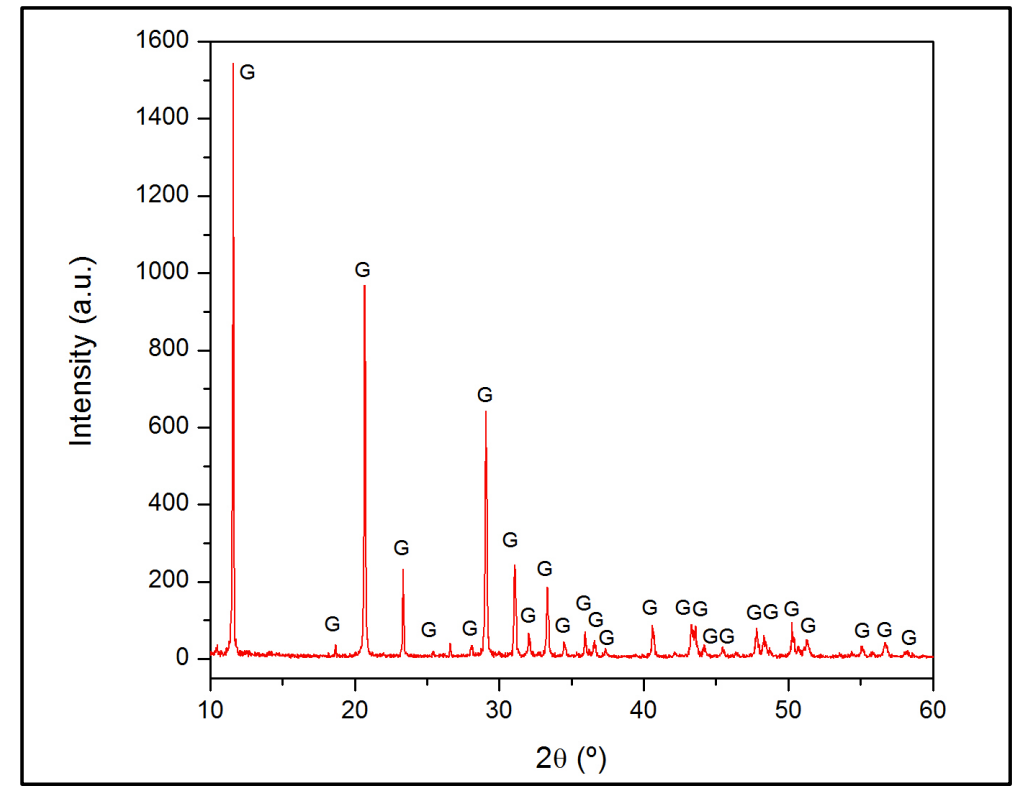

Figure 7. XRD patterns of initial sample of gypsum rock ( $\mathrm{G}=\mathrm{Gypsum}$, JCPDS 01-070-0982).

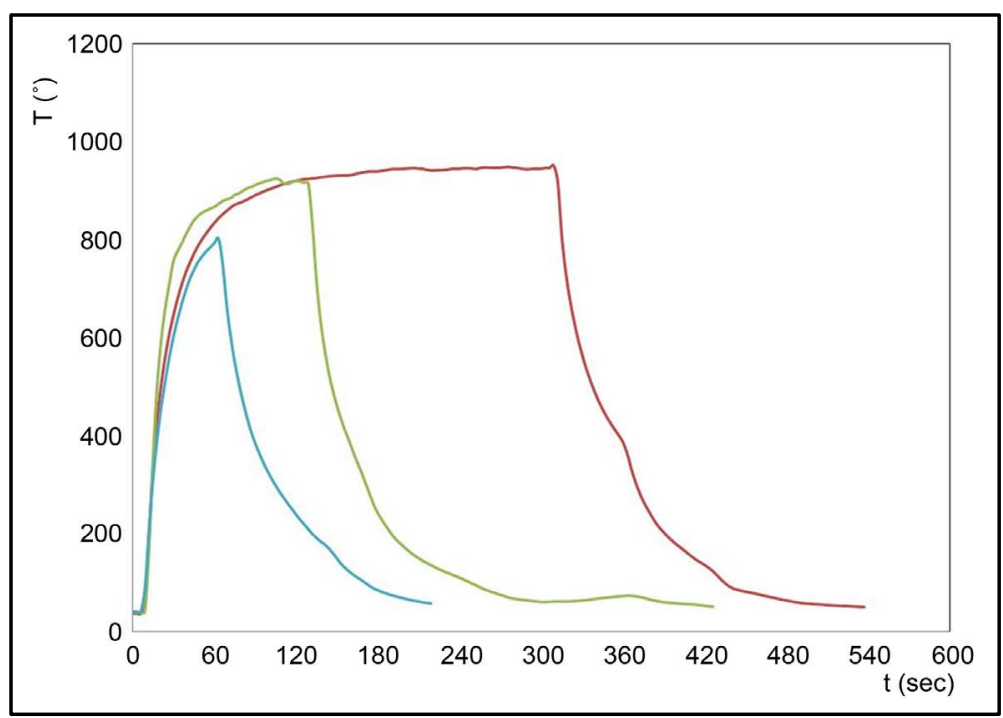

Figure 8. Curves of the evolution of temperature during different exposure time to solar radiation.

Concerning the coarsest sample G4, for five minutes of solar radiation exposure, (Figure 10), the three phases can be observed and the crystallinity of the phases anhydrite and bassanite are lower for this sample than for lower grain size samples (G1 and G2). 


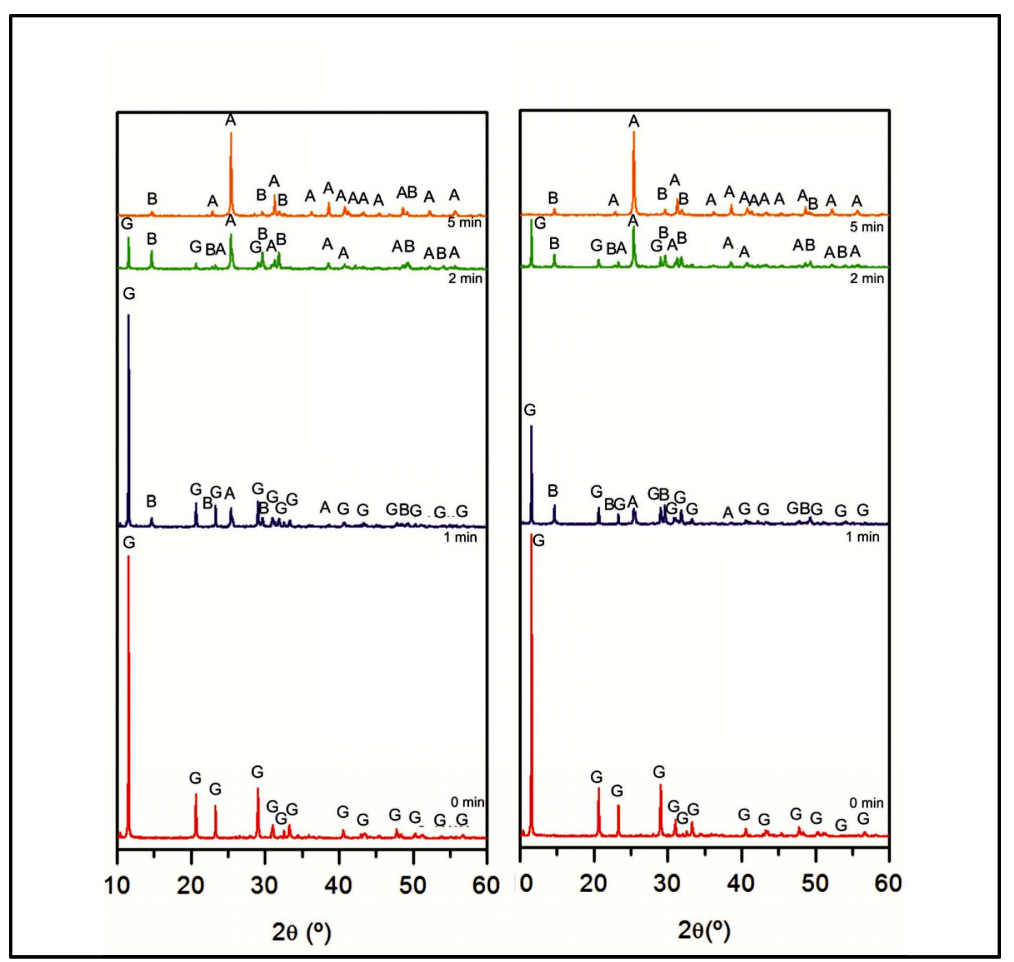

Figure 9. XRD patterns of initial samples G1 (left) and G2 (right) after 1, 2 and 5 min of solar radiation exposure $(\mathrm{G}=$ Gypsum, JCPDS 01-070-0982; $\mathrm{B}=$ Bassanite, JCPDS 00-041-0224; A = Anhydrite, JCPDS 00-037-1496).

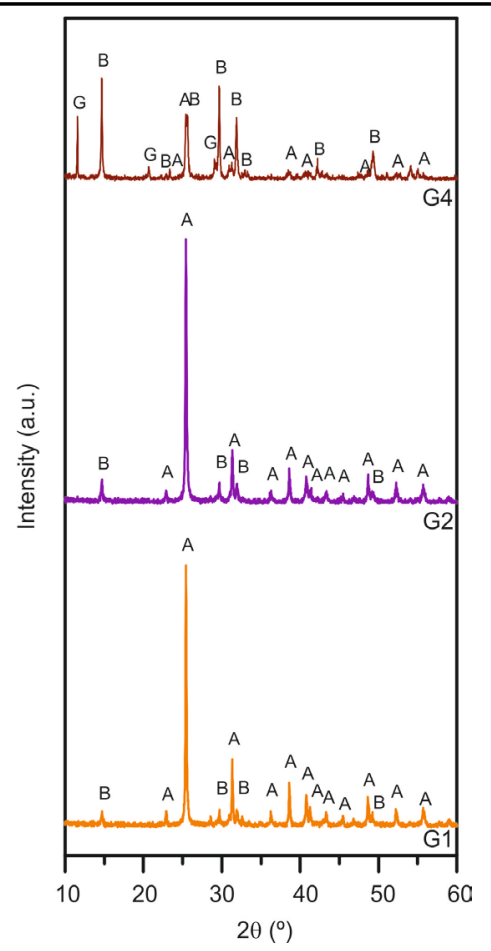

Figure 10. XRD patterns of initial samples G1, G2 and G4 after 5 min of solar radiation exposure ( $\mathrm{G}=$ Gypsum, JCPDS 01-070-0982; B = Bassanite, JCPDS 00-041-0224; A = Anhydrite, JCPDS 00-037-1496). 
The quantification of phases from XRD patterns [18] [19] is shown in Figure 11, where the evolution of gypsum-bassanite-anhydrite for samples G1 and G2 with the solar radiation exposure time can be seen. The percentage of gypsum decreases as the exposure time increases, but the transformation of the dihydrate is faster for the largest particle size sample during the first minute of exposure. For two minutes of exposure the effect is the opposite of the previous one; this could be attributable to the better heat transfer due to a better contact between particles due to their smaller size. For longer period of time $(5 \mathrm{~min})$ the transformation of the dihydrate is completed for the two samples according to XRD results. In the case of the hemihydrate phase (bassanite), its content increases in sample G1 from 1 (17.7\%) to $2 \mathrm{~min}$ (35.8\%) of exposure, but it decreases to $7.3 \%$ for $5 \mathrm{~min}$ of exposure. For sample G2, the transformation of bassanite into anhydrite is faster than in the previous one, and so for two min of exposure the content is lower than for $1 \mathrm{~min}$ (from $33.8 \%$ to $22.6 \%$ respectively). This means that transformation gypsum $\leftrightarrow$ bassanite is clearly grain size dependent [20]. The content of anhydrite phase increases with the exposure time for samples, with scarce particle size relationship.

For $5 \mathrm{~min}$, the quantification of XRD patterns corresponding to all samples (Figure 10) is collected in Table 2. The complete transformation of gypsum was attained for smallest particle size sample. This means that different final products can be designed by varying the particle size and the exposure time.

To study the particle surface of samples the coarsest sample was selected (G4). Figure 12 shows SEM images of a particle of G4 before (Figure 12(a)) and after (Figure 12(b)) solar radiation exposure (5 min). Before treatment samples exhibits the typical textures of gypsum consisting of flat faces with very definite edges, smooth and laminar structures. Gypsum is crystallized in prisms, most are "rhombohedral". After solar radiation, they appear textural differences due to dehydratation. Thus, the texture such as a "broken wooden floor" can be observed which is due to the modification of polyhedral arrangement in the non-hydrated phases and also it was observed the broken grain boundaries.

Figure 13 shows the topographic observation of the sample surface (G4) initial and after $5 \mathrm{~min}$ of exposure time. Although the layered structure of the initial sample was maintained during the solar radiation exposure, the smooth surface is transformed into a rough surface with roughness value of $0.44 \pm 0.01 \mu \mathrm{m}$. This means that roughness increased $30 \%$ with respect to the untreated sample.

\section{Conclusion}

This study demonstrated the viability of the use solar thermal energy for obtaining plaster from the calcination of gypsum rock. The influence of the grain size in the transformation gypsum-bassanite-anhydrite for different solar radiation exposure highly affect the mineralogical composition of the final product. Thus, for 5 min,

Table 2. Mineralogical composition of samples after $5 \mathrm{~min}$ of solar radiation exposure (wt\%).

\begin{tabular}{ccccc}
\hline Sample & Gypsum \% & Bassanite \% & Anhydrite \% & Gypsum dehydration (\%) \\
\hline G1 & - & 7.3 & 92.7 & 100.0 \\
G2 & 0.7 & 12 & 86.4 & 99.3 \\
G4 & 18 & 55 & 26 & 82.0 \\
\hline
\end{tabular}
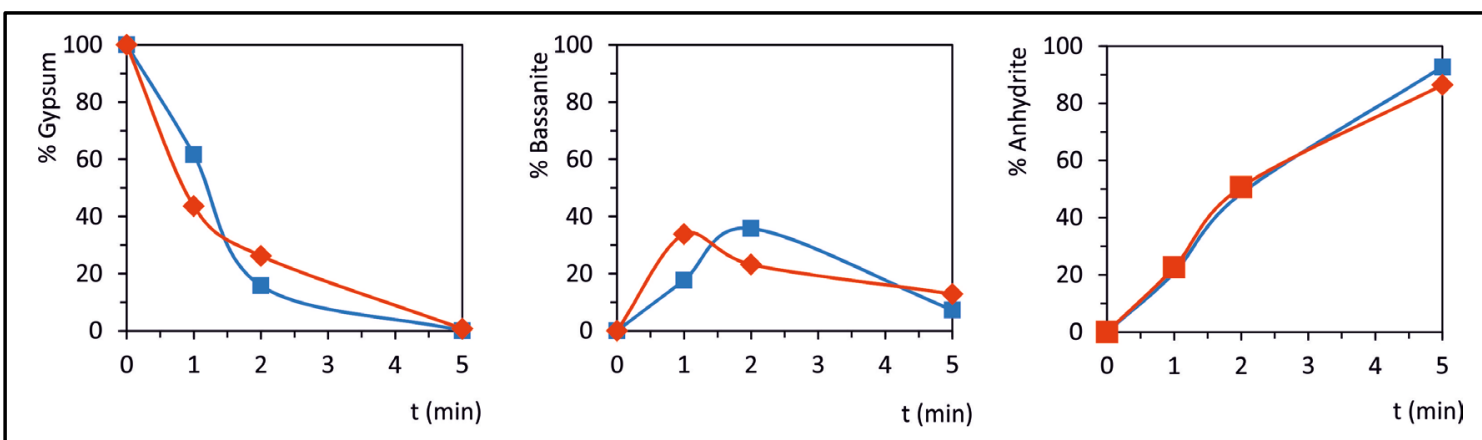

Figure 11. Evolution of $\mathrm{CaSO}_{4} \cdot \mathrm{H}_{2} 0$ phases for samples $\mathrm{G} 1$ and $\mathrm{G} 2$ for the different exposure time $(\square \mathrm{G} 1, \diamond \mathrm{G} 2)$. 

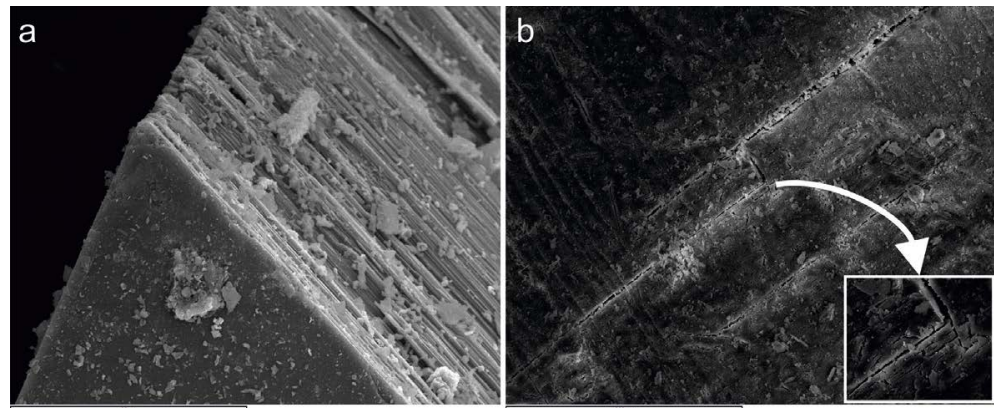

Figure 12. SEM images of G4: (a) before and (b) after 5 min of solar radiation exposure. A magnificated image is shown in the lower right corner.
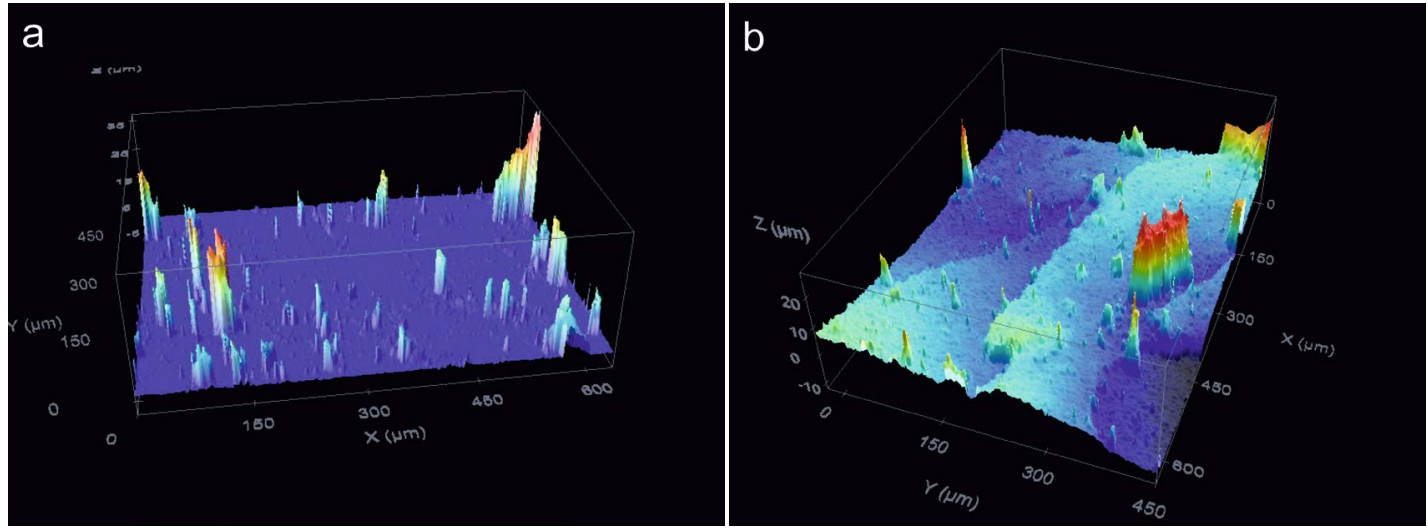

Figure 13. Topographic surface of G4 initial and after 5 min of solar radiation exposure.

plaster with different bassanite/anhydrite relationship can be obtained for samples with low grain size (lower than $4 \mathrm{~mm}$ ). For coarse sample (larger than $4 \mathrm{~mm}$ ) the plaster obtained is composed of the three phases. Different final products can be designed, selecting the adequate particle size of initial sample and the exposure time. This preliminary study can be the base of the future works on application of solar thermal energy to the treatment of gypsum-based materials, which due to their low cost should be treated by a low cost and environmentally friendly technology.

\section{Acknowledgements}

Authors thank to CSIC for the financial support and to CAI of Geological Techniques de la UCM for the technical support.

\section{References}

[1] Gunn, J.R. (1968) Evolution in Gypsum Mining. Gypsum Journal, 49, 14-18.

[2] Atedy: Asociación técnica y empresarial del yeso (2009) http://www.atedy.es/principal.asp

[3] Marchán Sanz, C. and Regueiro y González-Barros, M. (2011) Panorama Minero. Instituto Geológico y Minero de España (IGME)—Dirección General de Política Energética y Minas (Ministerio de Industria, Energía y Turismo). http://www.igme.es/internet/PanoramaMinero/actual/yeso\%2012.pdf

[4] Escavy, J.I., Herrero, M.J. and Arribas, M.E. (2012) Gypsum Resources of Spain: Temporal and Spatial Distribution. Ore Geology Reviews, 49, 72-84. http://dx.doi.org/10.1016/j.oregeorev.2012.09.001

[5] Sanz Arauz, D. (2009) Análisis de yeso empleado en los revestimientos exteriores mediante técnicas geológicas. Ph.D. Thesis, Universidad Politécnica de Madrid (UPM), Madrid.

[6] Wirsching, F. (2005) Calcium sulphate. Ullmanns's Encyclopedia of Industrial Chemistry. Wiley-VCH verlag GmbH \& со. KGaA, Weinheim.

[7] Escavy, J.I. and Herrero, M.J. (2013) The Use of Location-Allocation Techniques for Exploration Targeting of 
Place-Value Industrial Minerals: A Market-Based Prospectivity Study of the Spanish Gypsum Resources. Ore Geology Reviews, 53, 504-516. http://dx.doi.org/10.1016/j.oregeorev.2013.02.010

[8] Villanueva, L. (2004) Evolución histórica de la construcción con Yeso. Informes de la construcción, 56, 5-12.

[9] Xie, W.T., Dai, Y.J., Wang, R.Z. and Sumathy, K. (2011) Concentrated Solar Energy Applications Using Fresnel Lenses: A Review. Renewable and Sustainable Energy Reviews, 15, 2588-2606. http://dx.doi.org/10.1016/j.rser.2011.03.031

[10] Sierra, C. and Vázquez, A. (2005) High Solar Energy Concentration with a Fresnel Lens. Journal of Materials Science, 40, 1339-1343. http://dx.doi.org/10.1007/s10853-005-0562-6

[11] Romero, A., García, I., Arenas, M.A., López, V. and Vázquez, A. (2013) High Meting Point Metals Welding by Concentrated Solar Energy. Solar Energy, 95, 131-143. http://dx.doi.org/10.1016/j.solener.2013.05.019

[12] Nemet, A., Kravanja, Z. and Klemes, J.J. (2012) Integration of Solar Thermal Energy into Processes with Heat Demand. Clean Techn Environ Policy, 14, 453-463. http://dx.doi.org/10.1007/s10098-012-0457-6

[13] Llorente, J. and Vázquez, A.J. (2009) Solar Hardening of Steels with a New Small Scale Solar Concentrator. Materials Chemistry and Physics, 118, 86-92. http://dx.doi.org/10.1016/j.matchemphys.2009.07.008

[14] Puche Riart, O., Mazadiego Martinez, L.F., Ortiz Menéndez, J.E. and Llamas Borrajo, J.F. (2007) Historic GypsumKilns (Morata de Tajuña, Madrid). Materiales de Construcción, 57, 81-87.

[15] Sierra, C. and Vazquez, A.J. (2006) NiAl Coating on Carbon Steel with an Intermediate Ni Gradient Layer. Surface \& Coatings Technology, 200, 4383-4388. http://dx.doi.org/10.1016/j.surfcoat.2005.02.176

[16] Sobrino, J.A. (2000) Caracterización de una lente de Fresnel para la modificación superficial de materiales. Proyecto Fin de Carrera 99-01-106775, Universidad de Castilla-La Mancha (UCLM), Spain.

[17] Ferreire, A., Rodríguez, G.P. and Sobrino, J.A. (2004) Flux Distribution Delivered by a Fresnel Lens Used for Concentrating Solar Energy. Journal of Solar Energy Engineering, 126, 654-660. http://dx.doi.org/10.1115/1.1638783

[18] Chung, F.H. (1974) Quantitative Interpretation of X-Ray Diffraction Patterns of Mixtures. I. Matrix-Flushing Method for Quantitative Multicomponent Analysis. Journal of Applied Crystallography, 7, 519-525. http://dx.doi.org/10.1107/S0021889874010375

[19] Chung, F.H. (1974). Quantitative Interpretation of X-Ray Diffraction Patterns of Mixtures. II. Matrix-Flushing Method for Quantitative Multicomponent Analysis. Journal of Applied Crystallography, 7, 526-531. http://dx.doi.org/10.1107/S0021889874010387

[20] Van Driessche, A.E.S., Benning, L.G., Rodriguez-Blanco, J.O., Ossorio, M., Bots, P. and García Ruiz, J.M. (2012) The Role and Implications of Bassanite as a Stable Precursor Phase to Gypsum Precipitation. Science, 336, 69-72. http://dx.doi.org/10.1126/science.1215648 
Scientific Research Publishing (SCIRP) is one of the largest Open Access journal publishers. It is currently publishing more than 200 open access, online, peer-reviewed journals covering a wide range of academic disciplines. SCIRP serves the worldwide academic communities and contributes to the progress and application of science with its publication.

Other selected journals from SCIRP are listed as below. Submit your manuscript to us via either submit@scirp.org or Online Submission Portal.
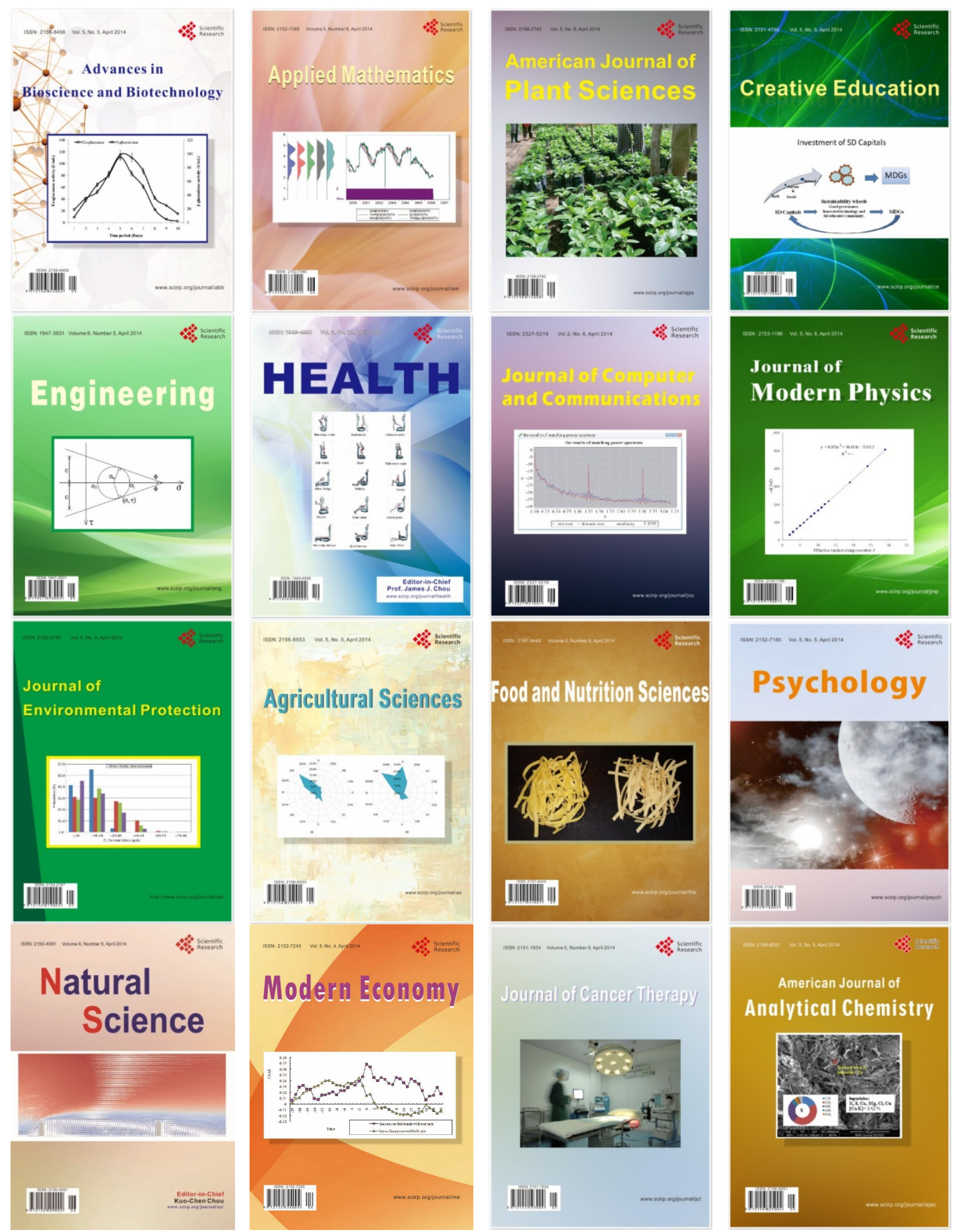